\title{
薄膜間の密着強度差を利用した多層配線の形成方法
}

\author{
青野 宇紀 ${ }^{1}$ ・岩崎 富生 ${ }^{2}$ \\ ${ }^{1}$ (株) 日立製作所 研究開発グループ 機械イノベーションセンタ 凿 312-0034 茨城県ひたちなか市堀口 832-2 \\ ${ }^{2}$ (株) 日立製作所 研究開発グループ 材料イノベーションセンタ 凿 319-1292 茨城県日立市大みか町 7-1-1
}

（2016 年 9 月 1 日受付；2016 年 12 月 3 日掲載決定）

\section{Fabricating Method for Multilevel Interconnection with Differential Adhesion Strengths between Metal and Silicon Oxide Thin Films}

Takanori AONO ${ }^{1}$ and Tomio IwASAKI ${ }^{2}$

${ }^{1}$ Hitachi, Ltd., Research \& Development Group, Center for Technology Innovation-Mechanical Engineering, 832-2 Horiguchi, Hitachinaka, Ibaraki 312-0034

${ }^{2}$ Hitachi, Ltd., Research \& Development Group, Center for Technology Innovation-Materials, 7-1-1 Ohmika-cho, Hitachi, Ibaraki 319-1292

(Received September 1, 2016 ; Accepted December 3, 2016)

\begin{abstract}
This research demonstrates a newly developed technique to fabricate multilevel interconnections with differential adhesion strengths between metal and silicon-oxide $\left(\mathrm{SiO}_{2}\right)$ thin films. In the field of micro electromechanical systems (MEMS), the various kinds of metals have been applied as functional materials, i.e. low resistance, high-temperature endurance, catalyst and so on. However, several kinds of metals are not applied on the $\mathrm{SiO}_{2}$ thin film, since an adhesion strength between metal and $\mathrm{SiO}_{2}$ thin films is not enough. Thus, the adhesion strengths (delamination energies) were estimated with a molecular dynamics simulation, and the metals of the lower wiring and the contact area were experimentally determined to easily fabricate the multilevel interconnections. Consequently, the $\mathrm{Cr}$, $\mathrm{Ti}$ and $\mathrm{Ni}$ thin films can be applied as the adhesion layer on the lower wiring, and the $\mathrm{Au}$ and $\mathrm{Cu}$ thin films can be applied as the release layer on the contact area.
\end{abstract}

KEYWORDS : MEMS, metal, silicon oxide, molecular dynamics simulation, delamination energy

\section{1.は じめ に}

近年, MEMS（Micro Electro Mechanical Systems）デバ イスでは，低抵抗，高温対応性，触媒機能などの観点か ら, 機能素子, 配線として, 様々な金属材料が適用され ている。しかし, 基板や絶縁膜との密着強度（剥離エネ ルギー）が低く, 剥離が課題となっている。MEMS デ バイスの加工プロセス設計において, 金属材料の選定 は, 機能の発現のみならず, 基板や絶縁膜との密着強度 を検討する必要がある。絶縁膜と密着強度の低い金属を 選定すると, 絶縁膜と金属との界面から剥離が発生する ため, 絶縁膜上に密着強度の高い金属を成膜し, その上

E-mail : takanori.aono.wh@hitachi.com
に密着性の低い金属を成膜した積層金属膜が適用されて いる ${ }^{1)}$ 。この積層金属膜の適用においても, 成膜条件, および積層金属膜形成後の加工プロセスの条件により, 基板上に形成した密着強度の高い金属中に, 密着性の低 い金属が拡散して, 絶縁膜から剥離する可能性がある。 したがって, 積層金属膜の適用に際しても, 加工プロセ スとの適合性を検証する必要がある。

MEMS デバイスにおいても，半導体デバイスと同様 に, 高集積化が進んで打り, 通信デバイス ${ }^{2,3)}$, 流体デ バイス ${ }^{4,5)}$ 等では, 機能素子から電気信号を取り出すた めに，多層配線や空間配線が利用されている。

本報告では, MEMS デバイスへの金属材料の適用, 高集積化対応の多層配線の形成のために，(1）分子動力 学シミュレーションを用いた絶縁膜 $\left(\mathrm{SiO}_{2}\right)$ と金属膜との 
密着強度（剥離エネルギー）の算出による金属材料の選 定，(2) 下部配線，コンタクト部に絶縁膜 $\left(\mathrm{SiO}_{2}\right)$ との密 着強度が異なる金属材料の適用により, コンタクト部上 のみの絶縁膜 $\left(\mathrm{SiO}_{2}\right)$ を容易に除去できる方法について紹 介し, 上記結果を基に, 薄膜間の界面の剥離エネルギー 差を利用した多層配線の加工プロセスについて検討した 結果について報告する。

\section{2. 解析および実験方法}

\section{1 分子動力学シミュレーションによる剥離エネル ギーの検討}

金属膜と絶縁膜 $\left(\mathrm{SiO}_{2}\right)$ との密着強度（剥離エネルギ 一）について, 元素間の結合を直接解析可能な分子動力 学シミュレーションを用いて検討した6,7)。Fig. 1 に, 金 属膜と絶縁膜 $\left(\mathrm{SiO}_{2}\right)$ との界面の解析モデルを示す。

剥離エネルギーの算出には, Fig. 1 (a) に示すよう に, 金属膜と絶縁膜 $\left(\mathrm{SiO}_{2}\right)$ とを接触させて, 平衡状態に なるまで緩和計算を行い, 接触状態でのポテンシャルエ ネルギー $E_{\text {connected }}$ を求める。

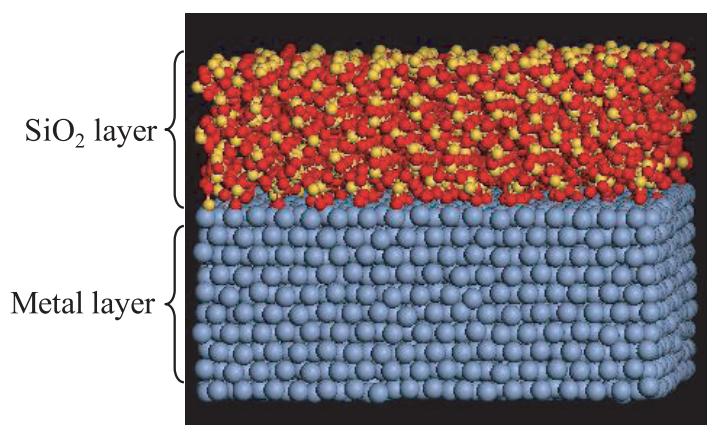

(a) Connected state

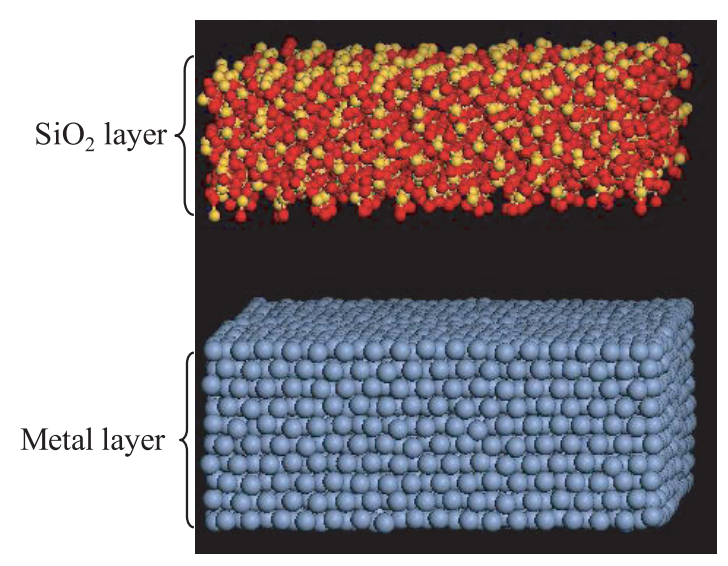

(b) Separated state

Fig. 1. (color online). Molecular dynamics simulation models for calculating delamination energy between $\mathrm{SiO}_{2}$ and metal layers.

$$
E_{\text {connected }}=\sum_{i<j} u\left(\left|r_{i}-r_{j}\right|\right)_{\text {connected }}
$$

ここで, $r_{i}, r_{j}$ は原子の位置, $u(r)$ は, 原子のポテンシ ヤルエネルギーである。緩和計算は, ニュートンの運動 方程式（質量 $\times$ 加速度＝力）に従って行う。次に, Fig. 1 （b）に示すように, 金属膜と絶縁膜 $\left(\mathrm{SiO}_{2}\right)$ とを分離 して，界面をまたぐ相互作用を消去して，緩和計算を行 うことで, 分離状態のポテンシャルエネルギー $E_{\text {separated }}$ を求める。

$$
E_{\text {separated }}=\sum_{i<j} u\left(\left|r_{i}-r_{j}\right|\right)_{\text {separated }}
$$

その後, 接触状態と分離状態とのポテンシャルエネル ギー差を算出することで, 金属膜と絶縁膜 $\left(\mathrm{SiO}_{2}\right)$ との相 互作用, すなわち剥離させるために必要な剥離エネルギ ーEを得ることができる。

$$
E=E_{\text {separated }}-E_{\text {connected }}
$$

本報告では, 剥離エネルギーを単位面積当たりの值と して算出するため, 最後に, ポテンシャルエネルギー差 を界面の面積で割って求めた。MEMS の分野で一般的

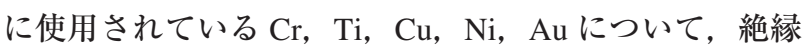
膜 $\left(\mathrm{SiO}_{2}\right)$ との剥離エネルギーを算出した。

\section{2 剥離エネルギー差を利用した加エプロセス}

Fig. 2 に, 半導体プロセスでの多層配線の加工プロセ スであるダマシンプロセス ${ }^{8)}$ を示す。下部配線を形成し た基板（Fig.2（a））上に, 下部配線と上部配線とを絶 縁する絶縁膜を形成する（Fig. 2（b）。次に，下部配線 と上部配線とを接続する部分にフォトリソグラフィ, エ ッチングでコンタクトビアを形成する（Fig. 2 (c)）。こ のコンタクトビア内に金属を電解めっきで埋め込み, コ ンタクト部を形成するため, 基板全面に給電用のシード 膜を成膜する (Fig. 2 (d))。次に, 電解めっきにより, コンタクトビアに金属を埋め込む（Fig. $2(\mathrm{e}))$ 。こ で, 電解めっきによる金属膜の成膜は, 給電したシード 膜上, すなわち基板全面に成長する。電解めっきで基板 表面に成膜された金属およびシード膜を CMP（Chemical Mechanical Polishing) で研磨する（Fig. 2（f)）。コン タクトビアに埋め込まれた金属は, 研磨されずにコンタ クト部として残存する。最後に, コンタクト部間を接続 する上部配線を形成して，多層配線を作製する（Fig. 2 $(\mathrm{g}))$ 。

Fig. 3 に, 金属膜と絶縁膜 $\left(\mathrm{SiO}_{2}\right)$ との密着強度を利用 した多層配線の加工プロセスを示す。基板上に $\mathrm{Al}$ を成 膜した後, フォトリソグラフィで, 下部配線のパターン を形成し（Fig. 3 (a))，Al 膜をエッチングして, Al 犠 牲層を形成する（Fig. 3（b)）。次に, 基板と密着強度の 


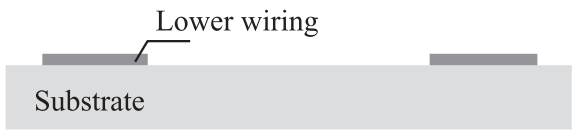

(a) Lower wiring fabrication

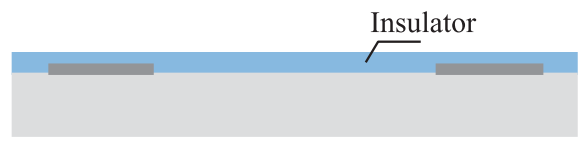

(b) Insulator deposition

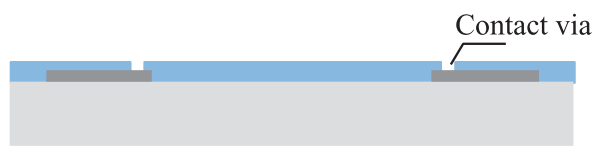

(c) Contact via fabrication

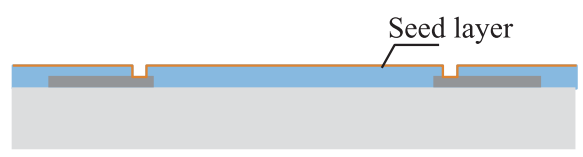

(d) Seed layer deposition

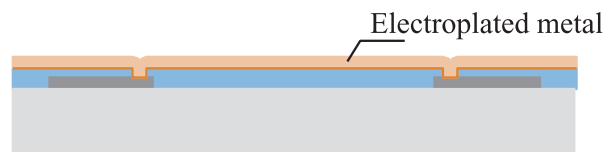

(e) Electroplating

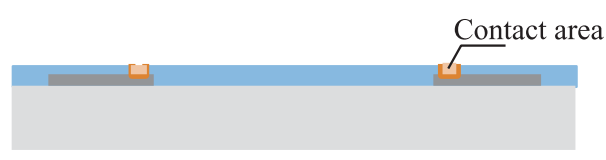

(f) CMP

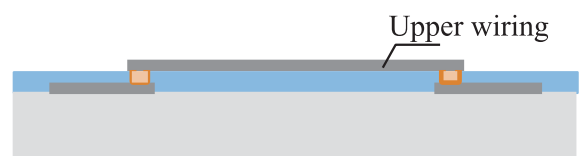

(g) Upper wiring fabrication

Fig. 2. (color online). Conventional fabricating process of multilevel interconnection.

高い金属, 機能金属膜, 絶縁膜と密着強度の高い金属の 順に成膜した後（Fig. 3（c)），レジストを有機溶剂で溶 かすことで，レジスト上の金属膜を除去でき，下部配線 を形成できる（Fig. 3 (d))。ここで, Al 犠牲層と下部 配線とは, 側面で接触しており, $\mathrm{Al}$ 犠牲層を電解めっ きの給電膜として適用することができる9)。次に，フォ トリソグラフィで, 下部配線上にコンタクト部のパター ンを形成した後 (Fig. 3 (e)), 電解めっきで下部配線上 にコンタクト部を形成する（Fig. 3 (f) )。

電解めっき後に, レジスト, $\mathrm{A} 1$ 犠牲層を除去して, 下部配線上にコンタクト部を形成した構造を形成する (Fig. 3 $(\mathrm{g}))$ 。次に, 絶縁膜 $\left(\mathrm{SiO}_{2}\right)$ をスパッタで成膜し

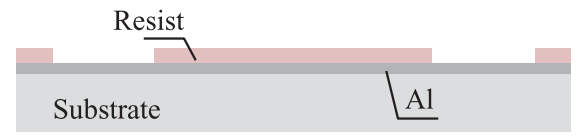

(a) Lower wiring patterning

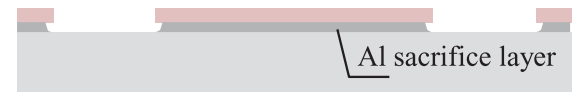

(b) Al sacrifice layer fabrication

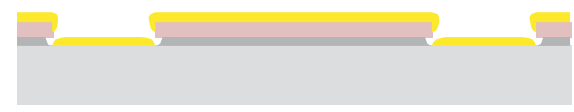

(c) Lower wiring sputtering

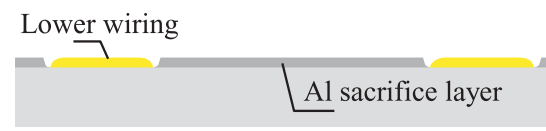

(d) Lift-off

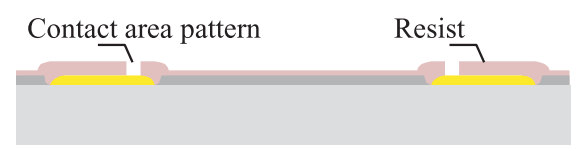

(e) Contact area patterning

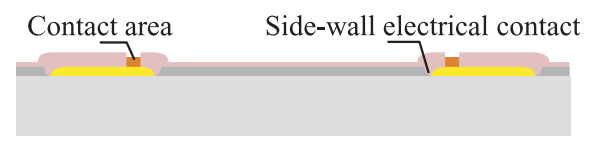

(f) Electroplating using side-wall electrical contact

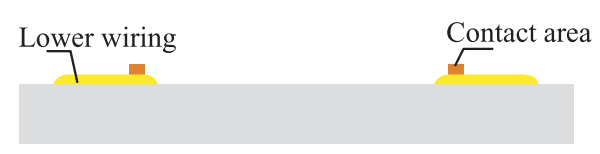

(g) Removal of resist and Al sacrifice layer

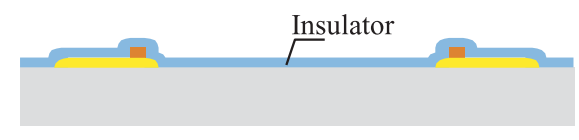

(h) Insulator deposition

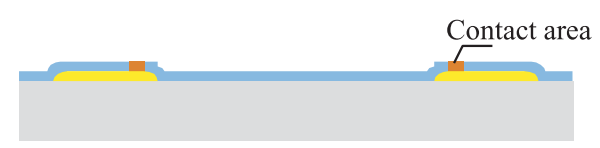

(i) Removal of insulator on contact area

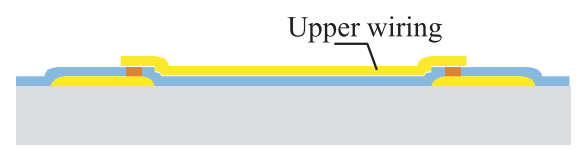

(j) Upper wiring fabrication

Fig. 3. (color online). Fabricating process of multilevel interconnection with differential adhesion strengths. 
た後（Fig. 3（h）），基板を純水中に浸漬して超音波を印 加することで，コンタクト部上の絶縁膜 $\left(\mathrm{SiO}_{2}\right)$ を剥離す る（Fig. 3（i））。超音波の印加には, 超音波洗浄機（W338 爆洗, 本多電子 (株) 製) を用いて, 出力 $600 \mathrm{~W} て ゙ 5$ min 間印加した。ここで, 絶縁膜 $\left(\mathrm{SiO}_{2}\right)$ と密着強度の低 いコンタクト部上の絶縁膜は剥離でき, 絶縁膜と密着強 度の高い下部配線上の絶縁膜は保持された構造を作製で きる。最後に, コンタクト部間を接続する上部配線を形 成して，多層配線を作製する（Fig. 3（j)）。

従来の方法では，CMP を適用した研磨によりコンタ クト部を形成していたが, 新規プロセスでは超音波印加 という比較的容易な方法で, コンタクト部上の絶縁膜 $\left(\mathrm{SiO}_{2}\right)$ を除去した構造を形成できる。

\section{3. 結果および考察}

\section{1 金属膜と絶縁膜 $\left(\mathrm{SiO}_{2}\right)$ との剥離エネルギー}

金属膜と絶縁膜 $\left(\mathrm{SiO}_{2}\right)$ との密着強度（剥離エネルギ 一）を分子動力学シミュレーションで算出した結果を Fig. 4 に示す。金属膜と絶縁膜 $\left(\mathrm{SiO}_{2}\right)$ との剥離エネルギ 一の大きさは, $\mathrm{Cr}>\mathrm{Ti}>\mathrm{Ni}>\mathrm{Cu}>\mathrm{Au}$ の順であり, 既に 報告されている密着強度 ${ }^{10,11}$ の傾向と一致している。こ の結果より，Fig. 3 に示した加工プロセスにおける下部 配線，コンタクト部に適用する材料を選定した。 $\mathrm{Cr}, \mathrm{Ti}$ は絶縁膜 $\left(\mathrm{SiO}_{2}\right)$ との剥離エネルギーが大きく, 基板㧍よ び絶緑膜 $\left(\mathrm{SiO}_{2}\right)$ との密着層として適用できる。したがっ て, Fig. 3 (c) に扔ける下部配線の上下面に, Cr, Ti を 積層しておくことで, 基板および絶緑膜 $\left(\mathrm{SiO}_{2}\right)$ との密着 性を向上することができる。一方, $\mathrm{Au}, \mathrm{Cu}$ は絶縁膜 $\left(\mathrm{SiO}_{2}\right)$ との剥離エネルギーが小さく, 基板および絶縁膜 $\left(\mathrm{SiO}_{2}\right)$ から剥離しやすいことがわかった。したがって, Fig. 3 (f)〜 (i) に扔いて, コンタクト部の材料として適 用することで, コンタクト部上の絶縁膜 $\left(\mathrm{SiO}_{2}\right)$ を除去で きる材料として選定した。

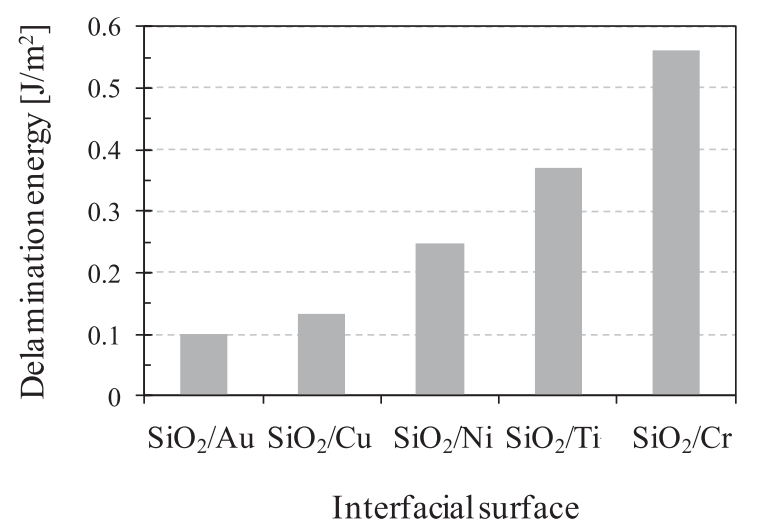

Fig. 4. Calculated results of delamination energies between $\mathrm{SiO}_{2}$ and metal layers with MD simulation.
本結果を検証するために, 下部配線を $\mathrm{Ti} / \mathrm{Au} / \mathrm{Ti}$ の積

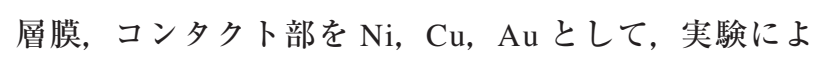
り, 絶縁膜 $\left(\mathrm{SiO}_{2}\right)$ の剥離について検討した。

\section{2 コンタクト部上の絶緑膜 $\left(\mathrm{SiO}_{2}\right)$ の剥離プロセス}

下部配線を $\mathrm{Ti} / \mathrm{Au} / \mathrm{Ti}$ の積層膜, コンタクト部に $\mathrm{Au}$ を適用した構造を形成し, 絶縁膜 $\left(\mathrm{SiO}_{2}\right)$ をスパッタで成 膜した。その後, 超音波の印加によりコンタクト部上の 絶縁膜 $\left(\mathrm{SiO}_{2}\right)$ の剥離を検討した。Fig. 5 に, 絶縁膜 $\left(\mathrm{SiO}_{2}\right)$ 成膜後, および絶縁膜 $\left(\mathrm{SiO}_{2}\right)$ 剥離後における下部 配線，コンタクト部の SEM 観察結果を示す。Fig. 5 (a) に示すように, 絶縁膜 $\left(\mathrm{SiO}_{2}\right)$ のスパッ夕後には, 下部配 線, コンタクト部の全面に絶縁膜 $\left(\mathrm{SiO}_{2}\right)$ が成膜されてい る。この基板を純水に浸漬して超音波を印加すると, Fig. 5 (b) に示すように, コンタクト部上のみの絶縁膜 $\left(\mathrm{SiO}_{2}\right)$ が剥離できていることがわかる。

超音波印加により, 絶縁膜 $\left(\mathrm{SiO}_{2}\right)$ を剥離した後の下部 配線, コンタクト部の元素を分析した結果を, Fig. 6 に 示す。コンタクト部からは, 絶縁膜 $\left(\mathrm{SiO}_{2}\right)$ に起因する $\mathrm{Si}, \mathrm{O}$ は検出されず, コンタクト部の $\mathrm{Au}$ のみが検出さ れた。一方, 絶縁膜 $\left(\mathrm{SiO}_{2}\right)$ と密着強度の高い金属材料 ( $\mathrm{Ti})$ を表面に用いた下部配線からは, 絶縁膜 $\left(\mathrm{SiO}_{2}\right)$ の $\mathrm{Si} ， \mathrm{O}$ ，および下部配線 $\mathrm{Ti}, \mathrm{Au}$ が検出された。この結

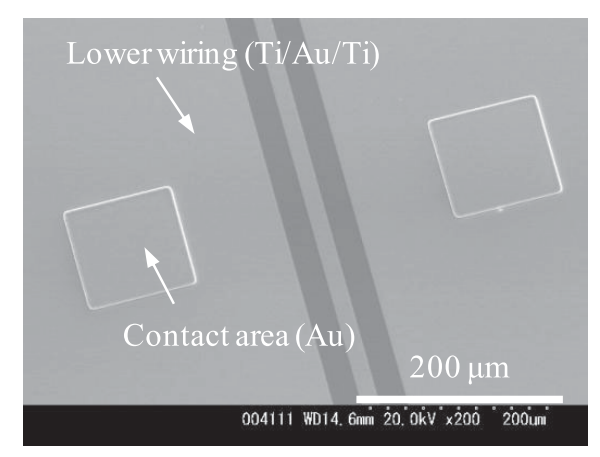

(a) Beforeremoval of $\mathrm{SiO}_{2}$ thin film on contact area

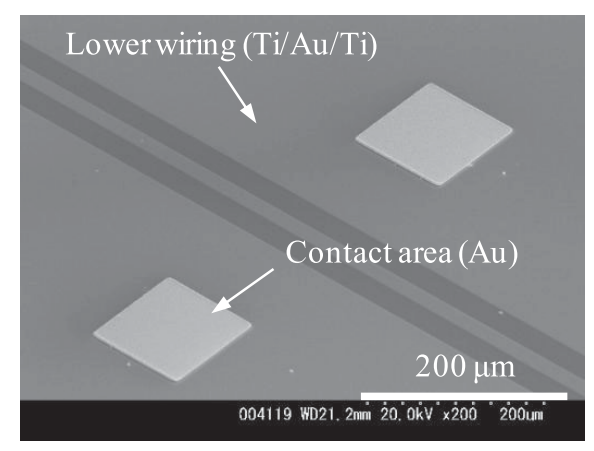

(b) Afterremoval of $\mathrm{SiO}_{2}$ thin film on contact area

Fig. 5. Photographs of lower wiring and contact area before and after removal of $\mathrm{SiO}_{2}$ thin film. 


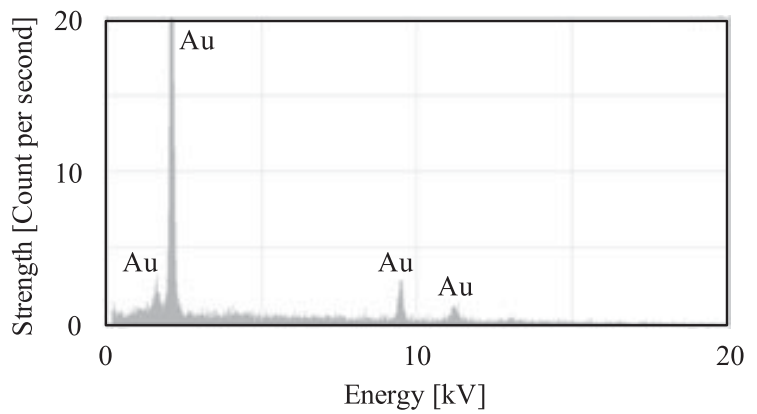

(a) Contact area

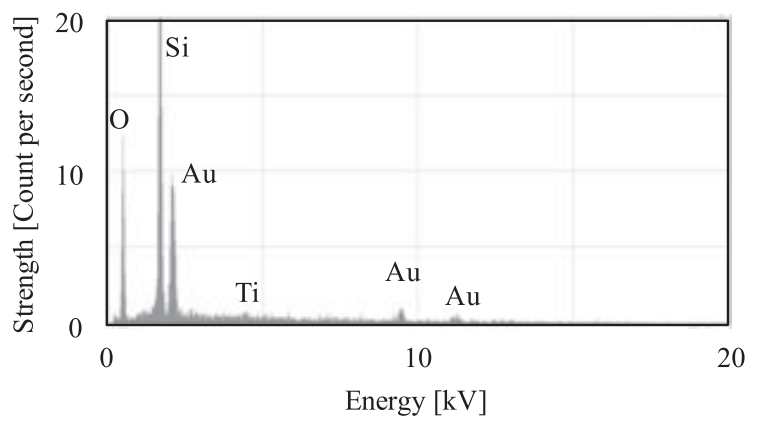

(b) Lower wiring

Fig. 6. EDX results of gold contact area and lower wiring.

果より, 絶縁膜 $\left(\mathrm{SiO}_{2}\right)$ と密着強度の低い $\mathrm{Au}$ をコンタク 卜部に, 絶縁膜 $\left(\mathrm{SiO}_{2}\right)$ と密着強度の高い $\mathrm{Ti}$ を下部配線 上に適用することで，コンタクト部上のみの絶縁膜 $\left(\mathrm{SiO}_{2}\right)$ を選択的に剥離できることがわかった。

Fig. 7 にコンタクト部に $\mathrm{Cu}$ を適用した場合, Fig. 8 に コンタクト部に Ni を適用した場合の SEM 観察結果, およびコンタクト部上の元素分析の結果を示す。Fig. 7 の結果より, コンタクト部に $\mathrm{Cu}$ を適用した場合, コン タクト部上からは, 絶縁膜 $\left(\mathrm{SiO}_{2}\right)$ に起因する $\mathrm{Si}, \mathrm{O}$ のピ ークはなく, $\mathrm{Cu}$ のみが検出され，超音波印加により， 絶縁膜 $\left(\mathrm{SiO}_{2}\right)$ が除去できていることを確認した。一方, Fig. 8 の結果より, コンタクト部に Ni を適用した場合, コンタクト部上からは, 絶縁膜 $\left(\mathrm{SiO}_{2}\right)$ に起因する $\mathrm{Si}, \mathrm{O}$ のピークが検出され, 超音波を印加しても, 絶縁膜 $\left(\mathrm{SiO}_{2}\right)$ は剥離せず, $\mathrm{Ni}$ のコンタクト部上に残存してい ることを確認した。

以上の結果より, 超音波印加による絶縁膜 $\left(\mathrm{SiO}_{2}\right)$ の金 属膜上からの剥離検討結果は, 分子動力学シミュレーシ ヨンで算出した剥離エネルギーの傾向と一致した。基板 および絶縁膜 $\left(\mathrm{SiO}_{2}\right)$ との密着層として, 密着強度の大き い金属 $\mathrm{Cr}, \mathrm{Ti}, \mathrm{Ni}$ を適用することで, 剥離のない配線 を形成することができた。一方, 絶縁膜 $\left(\mathrm{SiO}_{2}\right)$ と密着強 度の小さい金属 $\mathrm{Au}, \mathrm{Cu}$ をコンタクト部に適用すること で，コンタクト部上のみの絶縁膜 $\left(\mathrm{SiO}_{2}\right)$ を超音波印加と
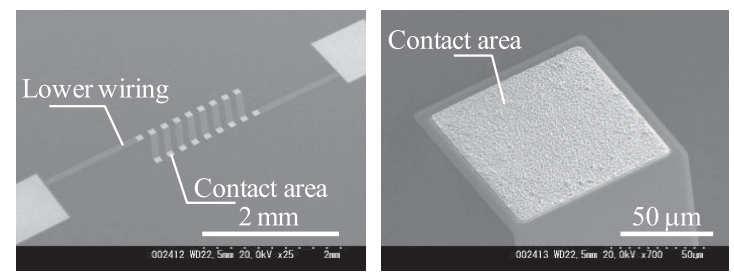

(a) SEM images of copper contact area

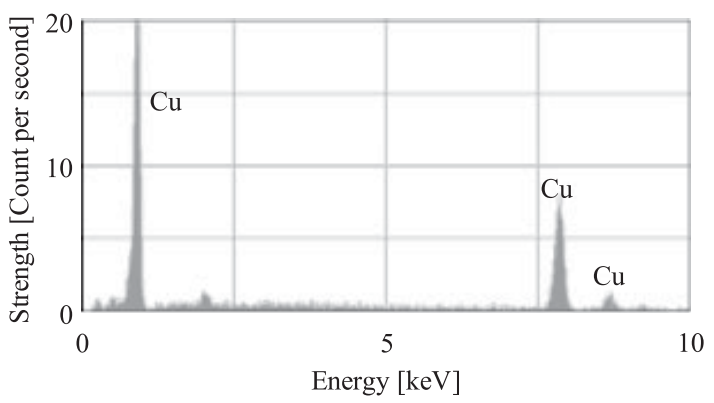

(b) EDX of copper contact area

Fig. 7. Photographs and EDX result of copper contact area.
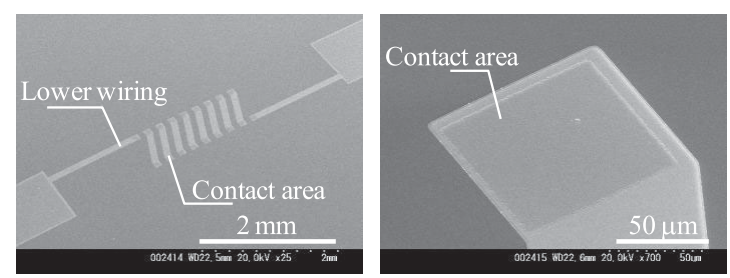

(a) SEM images of nickel contact area

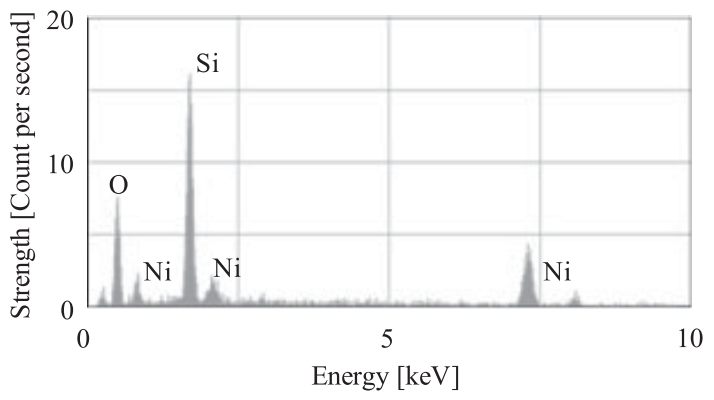

(b) EDX of nickel contact area

Fig. 8. Photographs and EDX result of nickel contact area.

いう比較的簡単な方法で，剥離できることがわかった。

Fig. 9 に, 絶縁膜 $\left(\mathrm{SiO}_{2}\right)$ との密着強度の差を利用して 作製した多層配線の一例を示す。Fig. 9（a）は，多層配 線の全体の観察結果, Fig. 9（b）は, コンタクト部の断 面観察結果, Fig. 9 (c) は, 下部配線と上部配線との交 差部分の観察結果である。Fig. 9（b）の結果より，コン タクト部 $(\mathrm{Au})$ 上の絶縁膜 $\left(\mathrm{SiO}_{2}\right)$ は, 超音波印加により 剥離でき, 下部配線と上部配線とは接続できていること 


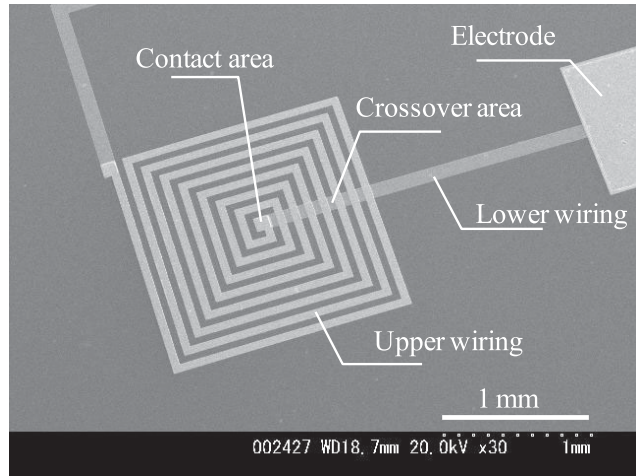

(a) Multilevel interconnection device

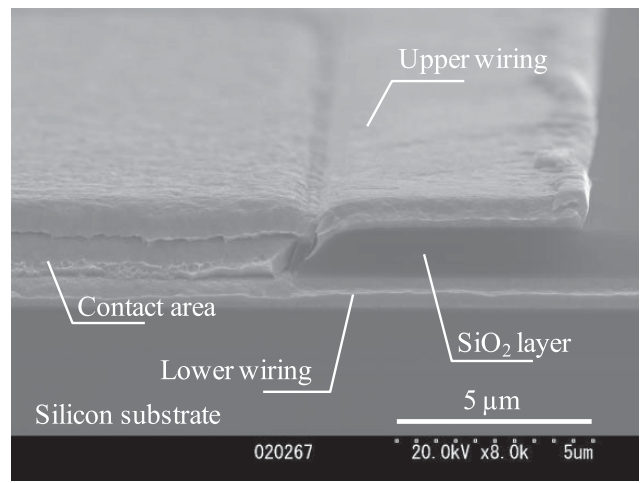

(b) Cross sectional view of the contact area

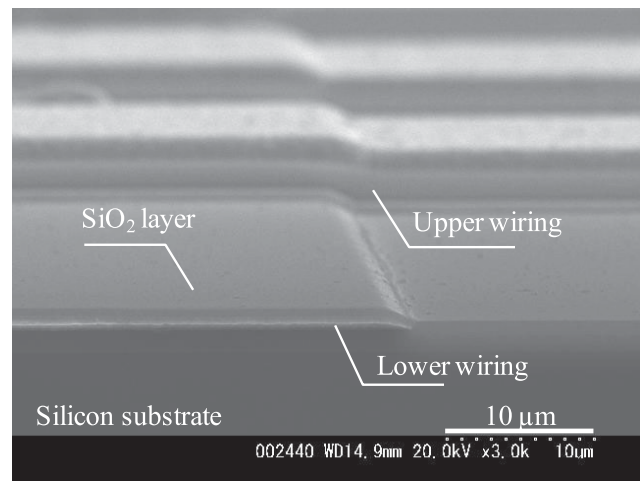

(c) Crossover area of the wiring

Fig. 9. Photographs of multilevel interconnection.

を確認した。また, Fig. 9（c）の結果より, 下部配線と 上部配線とが交差する部分においては，下部配線上の絶 縁膜 $\left(\mathrm{SiO}_{2}\right)$ の剥離はなく, 下部配線と上部配線とを絶縁 できることを確認した。以上の結果より，下部配線，コ ンタクト部に絶縁膜 $\left(\mathrm{SiO}_{2}\right)$ との密着強度差を設けた構造 を形成して，超音波を印加することで，下部配線上に は, 絶縁膜 $\left(\mathrm{SiO}_{2}\right)$ を保持した状態で, コンタクト部のみ の絶縁膜 $\left(\mathrm{SiO}_{2}\right)$ を剥離できた。この構造体上にコンタク 卜部と電極とを接続する上部配線を形成することで, 多 層配線を作製することが可能である。

\section{4. ま と め}

様々な金属材料を用いる MEMS デバイスでは，機能 の発現のみではなく, 膜間の密着強度, プロセス中の拡 散なども考慮する必要がある。本報告では紹介していな いが，プロセス中の拡散により, 密着強度が低下して, 金属素子の剥離が発生する事例があった。本報告では, 金属材料と絶縁膜 $\left(\mathrm{SiO}_{2}\right)$ との界面の密着強度を分子動力 学シミュレーションで見積もり, 絶縁膜 $\left(\mathrm{SiO}_{2}\right)$ が強固に 密着する部分, 剥離する部分を下部配線上に設けてお き, 剥離する部分の絶縁膜 $\left(\mathrm{SiO}_{2}\right)$ のみを選択的に剥離さ せる多層配線の加工プロセスへの適用例を紹介した。現 在, MEMS デバイスにおいて, 金属材料は機能素子, 配線以外にも半田を用いた接合材料などにも適用が進ん でいる。分子動力学シミュレーションによる拡散・反応 状態の把握, 加工プロセスの条件設定などを考虑するこ とで, さらに信頼性の高いデバイスの構築ができると考 えている。

\section{謝 辞}

本研究の一部は, 国立研究開発法人新エネルギー・産 業技術総合開発機構（NEDO）の委託を受けて実施し た。また，本報告の引用 ${ }^{12)} こ ゙$ 承諾頂いた一般社団法人 電気学会に感謝致します。

\section{文献}

1) P.T. Vianco, C.H. Sifford and J.A. Romero : IEEE Transactions on Ultrasonics, Ferroelectrics, and Frequency Control 44, 237 (1997).

2) H. Jiang, Z. Li and N.C. Tien : TECHNICAL DIGEST MEMS 2002 (2002) p. 649.

3) J-B. Yoon, B-I. Kim, Y-S. Choi and E. Yoon : TECHNICAL DIGEST MEMS 2002 (2002) p. 673.

4) J.K. John, E. Kim, H. Tu, J. Zhang, J.A. Loeb and Y. Xu : TRANSDUCERS 2013 (2013) p. 1476.

5) F. Xuan, X. Luo and I-M. Hsing : $\mu$ TAS 2012 (2012)p. 761.

6) F. Kuriyama, A. Fukunaga, A. Owatari, N. Saito and M. Nagai : Proc. of the ICEP 2008 (2008) p. 489.

7) T. Iwasaki and H. Miura: 1999 Material Research Society Fall Meeting 8. 4 (1999).

8) T. Iwasaki : JSME International Journal Series B 47, 470 (2004).

9) T. Aono, Y. Yoshimura, Y. Nakayama and M. Kanamaru : IEEJ Trans. SM 134, 20 (2014).

10）早川 茂, 和佐清孝: “薄膜化技術” (共立出版, 1982).

11) 日本学術振興会薄膜 131 委員会編 : “薄膜ハンドブッ ク” (オーム社, 1983).

12) T. Aono, T. Iwasaki, Y. Yoshimura and Y. Nakayama : IEEJ Trans. SM 135, 32 (2015). 